\title{
CONTEMPORARY ASPECTS OF EXTREMISM AND ITS SECURITY CHALLENGES
}

\author{
Olivera Injac, $\mathrm{PhD}$ \\ Faculty of Humanistic Studies UDG- Security Studies Program \\ E-mail: olivera.injac@udg.edu.me
}

\begin{abstract}
:
With a different violent forms and sorts, extremism continued progress in the 21'st century. Regardless sources that encourage it, violent extremism goes beyond national and regional borders and gets global tendencies. Waves of current violent religious extremism, have gained more importance with the spread of terrorism, especially because of the prominent impact on global security. Understanding of modern terrorism is not separated from the violent extremism and radicalization, which are considered as incentives for terrorism. The consistency of these security challenges is confirmed through their presence at all levels, from national and regional, to global security. The fact is that terrorism, violent extremism and radicalization are present in national security policies, as major challenges for security which need to be more efficient opposed. Reflection of the global challenges of spreading violent extremism and radicalization as an incitements for terrorism is quite present in the Western Balkans region. All Western Balkans countries have experienced these challenges, especially during the most dangerous phase of conflicts in Syria and Iraq 2012-2017, due to the participation of Balkan fighters in their battlefields.
\end{abstract}

Key words: violent extremism, terrorism, radicalization, security.

\section{Introduction}

Extremism, which is by default linked with severe security risks, such as terrorism, contributes to shaping global security paradigm in the 21st century. In its various forms and patterns of social expression, such as religious fundamentalism, radicalization, etc., it appears to give raise of a great wave of terrorist violence globally. Security challenges in the 21st century are linked with raise of religious terrorism, but also with the increase of radicalization that induces terrorism. The rise of the militant sanctity in the majority of religion (Apaduraj, 2008:13) has announced a wave of religious fundamentalism, which relies on the doctrine of spreading propaganda and negative attitudes against opponents, which implies insecurity and fear. Undoubtedly, terrorism 


\section{Securitity}

and religious extremism have become some of the greatest challenges for security, and they gain global scope and transform into a sort of 'epidemy', which threats all societies and countries. Global spread and impact of terrorism and religious extremism have been more intensively experienced since 2001, i.e. from 9/11 terrorist attacks on the United States.

Terrorist threats are present globally, either directly or indirectly, due to widespread classified networks and support of terrorist activities. A very clear example have been the attacks that occurred in recent years in some developed European countries, such as Belgium, France, Germany, England, Sweden and others. For this reason, terrorists are perceived as hidden (internal) enemies because they are most often involved within societies that they want to destroy. Special attention is drawn to the strong impact of Middle East conflicts (Syria, Iraq, Afghanistan), on strengthening of terrorist activities, especially through the spread of radical ideas and "foreign fighters" recruitment for the ISIL/Daesh.

According to the International Center for Research of Radicalization and Political Violence (ICSR), it is estimated that in Syria and Iraq, have been engaged large number of foreign fighters from all parts of the world, in last few years. These aspects of violent extremism, could affect states to decide on policy of isolation, in order to ensure long-term stability in a risky global environment.

\section{Violent Extremism Tendencies and Proportions}

Extremism is one of the modern challenges for security, what is indicated by its spread and influence on the global level. It is probably the most complex to understand phenomenon of extremism with radical and violent forms and their roots and causes, which are cause of modern terrorism in the 21'st century.

The basic characteristic of extremism is connection with religion or politics, regarding right or left orientations (Nohlen, 2001: 55) as well as relying on a concrete doctrine or tradition of understanding ideological or religious sources.

It is clear from a political point of view; extremism can have multiple meanings, but in this paper it will be analyzed as an incentive for terrorism and other types of extreme political violence. Extremism, by its basic characteristics, cannot be considered as a violent behavior, but we witness increase of violent extremism, which has direct imact on development of contemporary terrorism (Nünlist, 2015:2). There is a disagreement that concepts of violent extremism and terrorism are synonyms, although both are types of political violence. Concept of violent extremism is more intensely a part of the public discourse since 2005 , due to the previously politicized usage of the notion of terrorism through the concept "War on Terror" (Nünlist, 2015:2). Regarding tendency and extent of violent extremism, by assesment of the Intenational Center for Study of Radicalisation, it appears with phenomenon of radicalization, as a process of spreading ideas and beliefs that are incentive for terrorism (ICSR, 2015). As some analysis indicate, the term radicalization explains the process through which individuals are transformed and shaped into the violent extremists or terrorists (Nünlist, 2015:2). 
Direct link between radicalization and violent extremism have impact on the resilience of the society on phenomenologically caused stigmatization of all those who think differently and belong to nonviolent groups and movements.

Radicalization is directly related to violent religious extremism; whose consequences are widespread globally. With their influence are particularly vulnerable countries and regions, which face the new "fourth wave of terrorism", that have religious roots (Rapoport, 2004:61). This is particularly intensified with conflicts in Syria and Iraq, and contribution of "foreign fighters" in terrorist activities, after which often return to their country of origin.

Conceptual elements of the security challenges extremism and radicalization are connected with basic dimensions of religion. The discourse of understanding terrorism has changed over time, so terms such as Islamic terrorism, Islamic fundamentalism and others, are used for explanation of the specific form of terrorism, which is linked to the interpretation of the Islam religion. That approaches have led to the generalization of this complex phenomenon of religious terrorism, therefore in this paper, due to tendency to avoid uncritical generalization, this specific form is defined as "terrorism that refers to Islam"22.

In addition to the other challenges, it is considered that security also could be threatened by the religious fundamentalism, under which Kincler (2002:15) implies various religious actions that strive for change. The increase of religious fundamentalism that refers to Islam is particularly prominent because of the rise of violence, which is carried out under the patronage of the religion or politics (Injac, 2016:89). The existence of these phenomena in societies is a signal of a non-reselience and uncertainty, due to the complex impact of extremism and radicalization on security. However, despite its seriousity and degree of threat, violent extremism and radicalization jeopardizing the security of states and societies, it can be concluded that there is no universally accepted approach for understanding these concepts.

The term radicalization is part of the Western discourse, but it is particularly prominent after the terrorist attacks in the early 2000's in the United States and Europe. Under this term, we understand processes that lead people to extremism. In actual tendency of the violence proliferation reported by the terrorist organization ISIL/Daesh, especially since the intensification of terrorist activities since 2014, violent extremism and radicalization are unavoidable factors their activities globally.

The newest examples of terrorist actions in Europe (Figure 1) give a proof of the extension of insecurity and uncertainty era, which began with the 2000s terrorist attacks, which confirmes the idea of the 'risk society' (Mythen, 2004:2).

22 This explanation is used by author of the paper, in addition to avoid generalization and stigmatization of the general principles of the Islam religion. 


\section{Security}

\section{ISLAMIST TERROR ATTACKS IN EUROPE IN 2017}

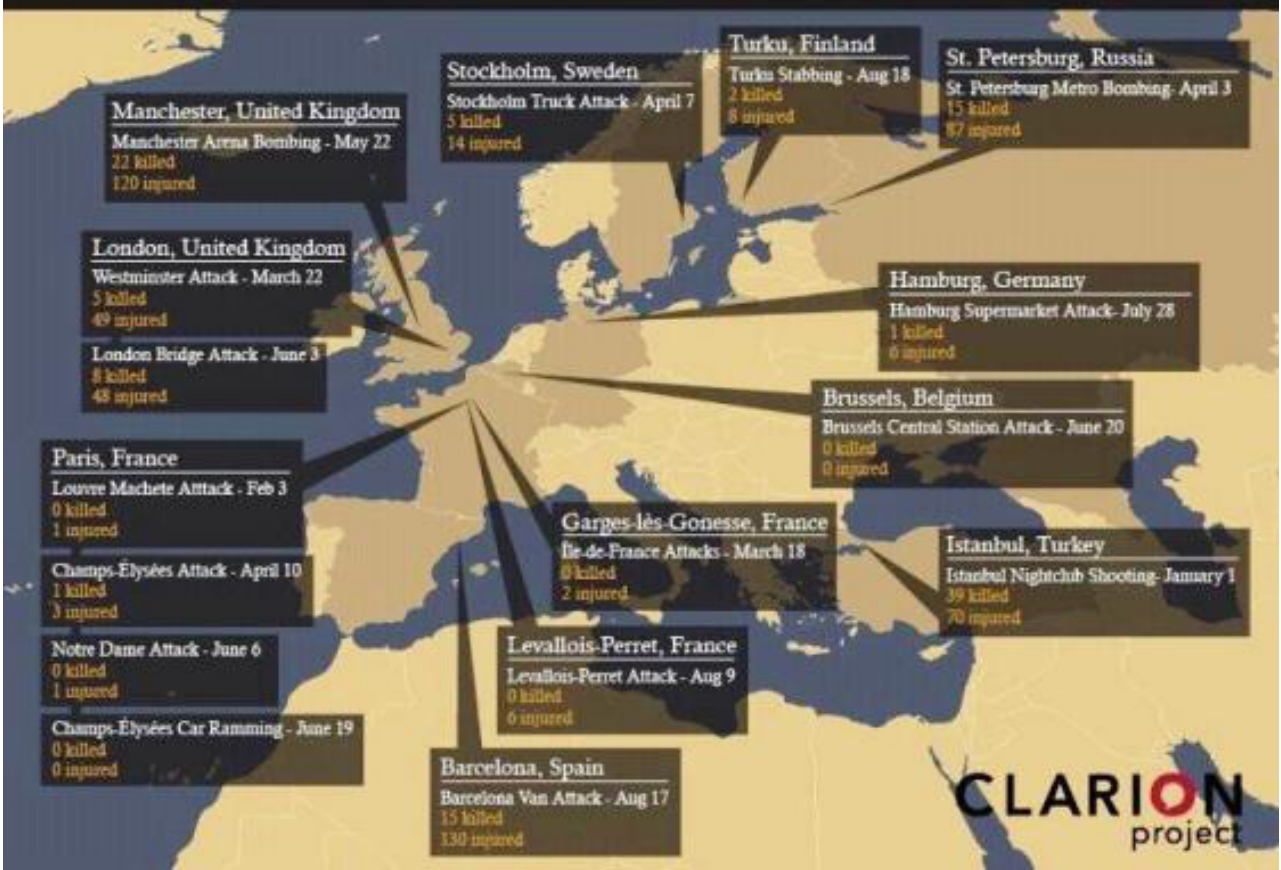

Figure 1: Terrorist attacks in Europe in $2017^{23}$

Problems with violent extremism, radicalization and terrorism have been present in Europe. Yet, the real expansion of this problem has occurred during the last few decades, with tendency of rise of religious radicalization and recruitment among the younger population (Wilkinson, 2005:33). The study of origin and the causes of radicalization is associated with multiple factors. Problems with radicalization a cause pressure and serious risks in societies, due to several important components characteristic for radicalized persons, such as a strong sense of indignation, defiance, persecution and deny of adjustment (ICSR, 2015). The aim of radicalization spreading is tendency to promote extremist religious ideas and values. As confirmation of presence and support for radicalization in Europe, are facts about large number of those who participated in foreign warfare or joined ISIL/Daesh. It is about 3,000 from Western Europe since the beginning of the conflict in Syria_until 2014 (Brigs and Silverman, 2014:6).

Recent data show a trend of the EU citizen's participation in the foreign battlefield and terrorist activities: as it was the case in the period of 2011-2017 when more than 5000 EU citizens

\footnotetext{
${ }^{23}$ According to data collected of registered terrorist attacks under the CLARION project (Figure 1), it is noted that in 2017, terrorist attacks were comitted in nine European countries, and the most of them were in France and England.
} 
were in Syria and Iraq (Azinović and Bećirević, 2017: 12). It is challenge for the security of the country of origin as well as for the entire region of Europe, since it is believed that upon return, they continue radicalization in their surroundings or support terrorist activities, because they are experienced war veterans. The expansion of violent extremism and radicalization gain global dimensions, although experts point out that there is no universal form of radicalization, but is different from the circumstances and location, ideas and narratives (Brigs and Silverman, 2014:6).

However, that non-existence of unique patterns of radicalization complicates a state's efforts to discover radicalization and to use countermeasures (deradicalization) that is of high priority in countering terrorism. Neumann believes that although there is no standard cause of radicalization, and therefore no confirmed profile of terrorists, that a more reliable assessment can be done by analysis of the factors that repeat (Neumann, 2017:19), such as:

- dissatisfaction - caused by numerous reasons (social tensions, conflicts, feeling injustice, marginalization and exclusion);

- needs - if individual belong to extremist group, his emotional needs are satisfied (group belonging, importance, power, adventure, popularity, etc.), what shown psychological weakness;

- ideas - it is basic incentive, replacement for dissatisfaction and justification for sacrifice;

- people - radicalization is a social process, carried out by authorities, charismatic leaders or influential groups that can gain trust, loyalty and attachment;

- violence - conducting violence is part of the organized and incentive activities that stand behind, and very often are inevitable part of violent conflicts.

\section{Global Dimensions of Violent Extremism and Terrorism}

Terrorism, as a form of political violence, has evolved and progressed, especially through the internationalization, i.e. the so-called 'third wave' of terrorism. According to the chronology of the terrorism development given by the British expert David Rapoport (2004: 61), this wave took place during the second half of the $20^{\text {th }}$ century. The specifics of the current 'fourth wave' terrorism indicate that its tendencies are related to sophisticated forms of gaining and winning long-term goals. The emergence of the new form of terrorism, which terrorist organizations associate with religious purposes, and with applying extreme methods of action in the 21st century, have the following characteristics (Kegli, 2003: 9):

- Global proportions - openness of societies and borders have created conditions for global terrorist activities;

- Unlimited violence - non-selectivity of targets and destructiveness in the realization of attacks;

- Civilians are target- victims of attacks are citizens, violence is carried out indiscriminately and indefinitely;

- Modern technologies- modern technologies are available for terrorists; 
- Enforced with extremism - obvious example is the most extreme terrorist tactic "suicide bombing", not just cause mass suffering, but also that tactic is evidence of terrorist readiness to sacrifice life for ideas they believe in;

- Emphasized animosity and extremism - rationality and insensibility of terrorists for victims suffering;

- The uncertainty of new challenges - unpredictability of terrorist attacks, and uncertainty of new terrorist trends, but also connection with other security challenges and extremist action.

Terrorist threats are spread in all regions, and influence phenomenon of the culture of fear, uncertainty and risk. Doubts on existence terrorist cells, which belong to terrorist network Al Qaeda and ISIL/Daesh, few times are confirmed in some European countries, and through evidence have been confirmed extremist activities and readiness on careless destructiveness (Delpech, 2002: 15).

Since the 2001 terrorist attacks, the number of victims and others social consequences of violent extremist actions have increased globally. Organizations with global activities, such as Al Qaeda, ISIL and Al- Nusra Front (UN Security Council, 2014), and those that operate in the region Africa (Boko Haram in Nigeria and Al- Shabab in Somalia and Kenya), with violent extremist's action advocate for long-term religious goals. However, Liang (2015: 2) believes that ISIL/ Daesh differs from others terrorist organization because of numerous reasons. The greatest goal of ISIL/ Daesh is a creation of a (pseudo) state or "Islamic Caliphate" at large territory of Middle East and others region, globalist and apocalyptic ambitions, and powerful media influence, that enable ISIL to recruit large number of 'foreign fighters'.

The impacts of the conflicts in some regions (Syria, Iraq, Afghanistan, etc.) have contributed to the global strengthening of terrorist activities, in particular through the dissemination of extremist ideas and through the radicalization within the societies. It is precisely the characteristic of violent religious extremism that is not only linked to individual terrorist attacks but is a part of the conflicts that involve a big number of victims (Nünlist, 2015: 1). A key component for the global prevalence of this challenge is conditioned by a large number of foreign fighters, who are recruited from all parts of the world. It is estimated that in period 2011-2017, about 43,000 people from 120 countries, participated in Syria and Iraq conflicts, and a very important fact is that 7,900 of them were coming from the Western countries (Azinović and Becirević, 2017: 12). It is not easy to highlight causes, as well as consequences of violent religious extremism. However, the fact is that they are structurally related to one of the following aspects (Nünlist, 2015: 1):

- -unresolved political conflicts,

- -insensitivity on human casualties and carelessness for infrastructure,

- -human rights violations,

- -discrimination and marginalization on religious and ethnic basis,

- -socio-economic vulnerability and inequality,

- -lack of good governance, and non-integration of migrant communities. 
After recent terrorist attacks in Europe, it came into focus a question of the size of violent religious extremism and radicalization, especially due to the possible connection with a large flow of migrations into Europe, migrants from the Middle East and Africa. According to Neumann (2017: 27), there is no reliable empirical evidence that migration can encourage terrorism; however, few attacks in Europe in recent years confirm the connection between migrants who have carried out attacks and terrorist organizations ISIL/ Daesha or Al-Qaida. There is no confirmation that these attacks were encouraged by radicalization of migrants in Europe. In that cases, radicalization of such individuals occurred in the countries of their origin and for the realization of terrorist attacks, they used migration flows to enter in European territory.

\section{Approaches in Understanding Violent Extremism in the Western Balkans}

The reflection of the new trend of terrorism that refers to Islam, or the so-called 'fourth wave' of terrorism, is also present in the Western Balkan region. Evidently, all countries (BiH, Serbia, Macedonia, Montenegro, Albania and Kosovo) are facing various aspects of extremism security risks and challenges. In many ways, there is a reflection of radicalization and violent extremism, but three manifestations in this region are especially emphasized: propaganda, support and recruitment for terrorist activities.

This region is recognized as a zone for the transit and recruitment of "foreign fighters" (Azinović and Jusić, 2015: 34), and large number of surveys show different data on the number of individuals and families who at battlefields in Syria and Iraq. Challenges of terrorism and radicalization that the region face are outlined in some of the research conducted by the BIRN (Balkan Investigative Reporting Network), which indicates that propaganda activities and the distribution of hate speech, recruitment and the creation of a support network are mostly realized online, through social networks (BIRN, 2017).

Although the challenges which the Western Balkan regionis facing are a part of the global trends of terrorism, countries have various experiences. Due to internal circumstances and conditions (e.g. frozen conflicts, political tensions, socio-economic crisis, etc.), some of them are more vulnerable for impact of terrorism, violent extremism and radicalization. In 2016, BIRN prepared qualitative analysis of the Western Balkans (Albania, BiH, Montenegro, Kosovo, Macedonia and Serbia) experiences with radicalization, recruitment and foreign fighters who participated in the conflicts in Syria and Iraq. Analysis was prepared from collected data within the project "Balkan Jihadists - Radicalization and Recruitment of Fighters in Syria and Iraq". In addition, recent study about these challenges, published by the Regional Cooperation Council $(\mathrm{RCC})$, indicates current trends and experiences of the region, as well as the capacities that the countries of the region have. It follows the analysis of the situation in six WB states: 


\section{Security}

ALBANIA is facing radicalization and other related challenges, especially in the context of the distribution of extremist ideas in certain religious sites, where recruitment problems are also observed, as well as the treatment of returnees from foreign battlefields (BIRN, 2016). According to the data of the State Prosecutor's Office, 107 citizens of Albania for period 2011-2015 participated in foreign fights (BIRN, 2016). In another study, for period 2012-2017 it was 144 persons (79 men, 27 women and 38 children) (Azinović and Bećirević, 2017: 22). It is believed that this problem in Albania can be controlled if national authorities initiate rehabilitation programs for returnees and improve measures to prevent online radicalization at young population.

BOSNIA AND HERZEGOVINA has already been a destination for foreign fighters during the 1990's conflict. Nevertheless, it has been renewed since 2012, due to the departure and return of foreign fighters, which security agencies assess as the biggest security threat in Bosnia (BIRN, 20 16:11). Data from the RCC study indicate that 287 persons from BiH years (172 men, 58 women and 57 children) contributed to Syria and Iraq conflicts in the period 2012-2017. In 2015 in Bosnia and Herzegovina were two terrorist attacks, one committed member of the Salafi community who killed a police officer in Zvornik (Republika Srpska), and in second attack are killed two members of the Bosnian Armed Forces in Sarajevo, after which attacker-committed suicide. In addition, BIRN's analysis indicates impact of online radicalization, as well as illegal religious objects, known as "paragemats". Number of these controversial objects in Bosnia and Herzegovina is unknown, because they are out of state control (BIRN, 2016:13). Concerns also comes from socio-economic conditions (unemployment, poverty, lack of education, etc.), which makes Bosnian society even more vulnerable and favor the spread of radicalization.

MONTENEGRO, like other countries in the region, faces the challenges of radicalization and extremism. The data shows that incomparably smaller number of Montenegro citizens, compared to other countries in the region, were at the Syrian and Iraqi battlefields for the period 20122017. In total it was 27 persons (18 men, 5 women and 4 children) (Azinović and Bećirević, 2017: 22). Radicalization is registered by the security services of Montenegro, and that challenge is particularly present in the Sandžak region, from where persons mostly participate in a foreign battlefield (BIRN, 2016: 33). One of the extremist videos distributed through the social network, referred to addressing from Syrian militia fighter, originally from Montenegro, who called Muslims to join the Holy Caliphate War (BIRN, 2016: 32).

KOSOVO case has more specific characteristics than other countries in the region, due to the pronounced tendencies of citizens to join terrorist activities in Syria and Iraq. Namely, the data show the largest number of Kosovo persons in Syria and Iraq for the period 2012-2017, which is in total 399 persons ( 255 men, 48 women and 96 children, out of which 37 are believed to be born there) (Azinović and Becirević, 2017: 22). For that period, 110 returnees from the battlefield returned to Kosovo. Risk assessment on returnees to Kosovo, indicates that there are two main 
dangers- intent to commit terrorist attacks and the spread of radical ideas by returnees and their relatives (Azinović and Becírević, 2017: 22).

MACEDONIA - Experience with this challenge did not go beyond this Western Balkan country, from which 154 people (140 men and 14 women) for the period 2012-2017 participated at the battlefields of Syria and Iraq (Azinović and Bećirević, 2017: 22). This country's specificity, compared to others, is that the problem of ethnic tensions contributes to reducing efficiency in addressing challenges of extremism and radicalization (BIRN, 2016: 25). The reality of this problem in Macedonia depends on several factors, among which the influence of the Islamic population is being carried out through online radicalization or directly in religious facilities, and the rapid expansion is favorable for the existence of interethnic tensions between ethnic Macedonians and Albanians.

SERBIA - During the period of more intense conflicts in Syria and Iraq (2011-2017), 59 citizens ( 37 men, 12 women and 10 children) stayed at the foreign battlefield (Azinović and Bećirević, 2017: 22). The complexity of this phenomenon in Serbia is associated with strong network of violent extremists and adequate conditions for radicalization (BIRN, 2016: 25), especially in the Sandžak region, because of existing internal problems (poverty, lack of education, limitation of contacts within the social community and detachment) (BIRN, 2016: 42).

It is necessary for Western Balkan countries in a timely manner to develop strategic, institutional and other responses, in addition to adequately approach countering radicalization and violent extremism, and in particular, to avoid current problems with politicization, securitization and bureaucratization of these challenges (Azinović and Becirević, 2017: 9).

\section{Conclusion}

Suppression of terrorism depends on both, willingness of states to counter this security phenomenon, but also on comprehensive approach in preventing spread of ideas, which support terrorism. At the heart of problem of global expansion and terrorism impact on societies, there is an inadequate approach for reduction of extremism. States need to adopt policy for revealing motives of individuals to join extremist and terrorist activities.

Violent extremist movements increase in global level; however, some regions are more vulnerable to the risks of extremism and terrorism. For example, the phenomenon of terrorism and extremism is continuously challenged for Iraq, Afghanistan, Syria, Nigeria, Yemen and others. According to the Global Index of Terrorism, at these countries happened largest number of suicide bombers terrorist attacks (Institute for Economics and Peace, 2017), that is the most destructive form of terrorism. In most of regions, risk of terrorism is encouraged by some of the following facts: ISIL/Daesh actions, vulnerability of the territory and population, "foreign fighters", who are joining ISIL or provide support for radicalization, and more. 


\section{Secuurity}

The global security paradigm, at the beginning of the 21st century, depended on the activities of the terrorist organization Al Qaeda, but this primacy has been taken over for a few years by other organizations, which are Al Qaeda branches or descendants, as ISIL/Daesh and Al Nusrah Front (UN Security Council, 2014). These organizations use propaganda, violent actions and strategic influence, which contribute to the uncertainty caused by global spread of terrorism. However, the most worrying is the increase of radicalization, which encourages support for terrorism, through indoctrination and recruitment. Radicalization is increasingly prevalent in all parts of the world, what is enabled by internet, as the main means of extremist propaganda and promotion of terrorist ideas. The UN report highlight that extremist propaganda, conducted by ISIL and other organizations, has spread to the Middle East and the rest of the world, by digital way, through the Internet, social networks, videos and other forms for distribution of radicalization material (UN Security Council, 2014).

Challenges that cause extremism and radicalization, as a basis for terrorism are gaining global proportions, and their reflection has spread to the region of the Western Balkans. It is believed that efficiency of dissemination is conditioned by modern technologies for online propaganda. Security implications and challenges of extremism and radicalization are also conditioned by the vulnerability of societies and the lack of institutional responses by states to control and counter the causes and origin of these challenges.

\section{REFERENCES:}

1. Apaduraj, A. (2008) Strah od malih brojeva, Beograd. Biblioteka XX vek

2. Azinović, V. Bećirević, E. (2017) A Waiting Game: Assessing and Reporting to the Threat from Returning Foreign Fighters in the Western Balkans. Sarajevo: Regional Cooperation Council (RCC)

3. Azinović, V. Jusić, M. (2015) Zov rata u Siriji i Bosanskohercegovački kontigent stranih boraca. Sarajevo: Atlantska Inicijativa

4. Balkan Investigative Reporting Network, "Balkan Jihadists - Radicalization and Recruitment of Fighters in Syria and Iraq", BIRN (2016), available at:

5. https://www.balkaninsight.com/en/file/show/Balkan-Jihadists.pdf (visited on 01.12.2017)

6. Balkan Investigative Reporting Network - BIRN (2017) Balkan Insight. February 2, 2017

7. http://www.balkaninsight.com/en/article/balkan-jihadi-warriors-remain-safe-on-thenetj-01-27-2017 (visited on: 01.12.2017.)

8. Brigs, R Silverman (2014) T. "Western Foreign Fighters - Innovations in Responding to Threat", Institute for Strategic Dialogue.

9. Castells, M. (2002) Moć identiteta. Zagreb: Golden Marketing

10. CLARION Project (2017). All the Terror Attacks in Europe This Year. August 21, 2017 (online). https://clarionproject.org/terror-europe-next/ (visited on: 10 Decembar 2017)

11. Delpech, T. (2002) "International Terrorism and Europe", Chaillot Papers, no. 56/2002.

12. Institute for Economics and Peace (2017), Global Terrorism Index Report 
13. www.economicsandpeace.org (visited on: 01.12.2017)

14. International Center for Studying Radicalization - ICSR (2017) The roots of radicalisation? It's identity, stupid. London: Kings College. Department of War Studies.

15. http://icsr.info/2015/06/icsr-insight-roots-radicalisation-identity-stupid/, (visited on: 01.12. 2017)

16. Injac, 0. (2016) Bezbjednosne studije i kultura bezbjednosti. Beograd: FPN \& Čigoja štampa.

17. Injac, 0. (2011) Sociološki aspekti savremenog terorizma u Evropi. Beograd: Udruženje za političke nauke \& Čigoja štampa.

18. Kincler, K. (2002) Verskifundamentalizam. Beograd: CLIO.

19. Kegli, Č. (2003) The new global terrorism:characteristics, causes, controls. New Jersey: Pearson Education.Inc.

20. Liang, C.S. (2015) "Cyber Jihad: Understanding and Countering Islamic State Propaganda", Geneva Centre for Security Policy Policy Paper 2015/2.

21. Mythen, G. (2004) Ulrich Beck - a critical introduction to the risk society. London: Pluto Press.

22. Nohlen, D. (2001) Politološki rječnik - država i politika. Osijek - Zagreb-Split: Panliber.

23. Neumann, P. (2017) Countering Violent Extremism and Radicalization that Lead to Terrorism: Ideas, Recommendations, and Good Practices from the OSCE Region (report). OSCE and ICSR. 28 September 2017.

24. Nünlist, C. (2015) The Concept of Countering Violent Extremism, CSS. no. 183, December 2015.

25. Rapoport, D. (2004) "The Four Waves of Modern Terrorism". In: Attacking Terrorism:Elements of a Grand Strategy. Washington, DC: Georgetown University Press.

26. UN Security Council (2014) The Islamic State in Iraq and the Levant and Al - Nusrah Front for the People of the Levant-report and recommendations submitted pursuant to Resolution 2170.

27. Wilkinson, P. (2005) "International Terrorism - the changing threat and the EU's response", Chaillot Papers, no 84. 